МАРТИНЕНКО Олександр - кандидат філософських наук, докторант кафедри філософії, Чернівецький національний університет імені Юрія Федьковича, 2, вул. Коиюбинського, м. Чернівці, Україна, індекс 58000 (dr.martynenko@gmail.com).

ORCID: http://orcid.org/0000-0002-1939-9387

DOI: https://doi.org/10.24919/2522-4700.43.12

Бібліографічний опис статті: Мартиненко, О. (2021). Синтез у статичному й динамічному аспектах в генології Парменіда та Геракліта. Людинознавчі студї: збірник наукових пращь Дрогобицького державного педагогічного університету імені Івана Франка. Серія «Філософія», 43, 89-95, doi: https://doi.org/10.24919/25224700.43.12

\title{
СИНТЕЗ У СТАТИЧНОМУ Й ДИНАМІЧНОМУ АСПЕКТАХ У ГЕНОЛОГІЇ ПАРМЕНІДА ТА ГЕРАКЛІТА
}

Анотація. Метою статті є історико-філософський аналіз античних витоків синтезу в генологіі Парменіда і Геракліта, їх порівняння та зіставлення з гетелівською моделлю синтезу. Методологічні засади дослідження: основний метод - історико-філософський. У статті також застосовано порівняльний і структурно-функиіональний методи. Використовуються загальнонаукові методи: аналіз, синтез, узагальнення, абстрагування тощо. Наукова новизна. Історично склалося так, щзо онтологія (метафізика буття) зайняла домінуючу позицію в сучасній філософії, відсунувши на другий план генологію (метафізику єдиного). Категорії «буття» $i$ «єдине» почали вживатися як взаємозамінні, а іноді як рівнозначні. Це суттєво вплинуло на розвиток філософії загалом, змінивши специфіку самого способу мислення, зокрема когнітивної операції синтезу. Пояснення специффіки синтезу, як і спроби класифікаиії його різновидів, у більшості філософських пращь продовжує зберігати однозначність. Такий підхід став усталеним у модерній практиці філософування. Він не зазнав жодних змін у поглядах представників сучасної української філософії. Наявні визначення та класифікації операчії синтезу мають переважно описовий характер. Синтез у традииійному розумінні, як правило, асочіюється з ім'ям Г.В.Ф. Гетеля. Сучасна філософська рефлексія, що трунтується на критиці метафізики у ХХ ст., вимагає розв 'язання проблеми суперечностей. Саме тому важливо здійснити нові кроки в дослідженні історичних витоків появи операції синтезу, розкрити генологічну модель ї̈ здійснення, яка тривалий час залишалася в забутті. Висновки. У генологічному синтезі, на відміну від гетельянської моделі, суперечності є формальною умовністю. Відмінність статичної і динамічної моделей синтезу Парменіда і Геракліта полягає у виборі умов здійснення иієї операчії - «від єдиного» $i$ «о єдиного».

Ключові слова: синтез, генологія, онтологія, єдине, буття, одиничне, множинне, иіле, синкретичне, суперечності.

MARTYNENKO Oleksandr - Ph.D., post-doctoral student at the Department of Philosophy and Cultural Studies, Yuriy Fed'kovych Chernivtsi National University, 2, Kotsyubynskoho str., Chernivtsi, Ukraine, postal code 58000 (dr.martynenko@gmail.com)

ORCID: http://orcid.org/0000-0002-1939-9387

DOI: https://doi.org/10.24919/2522-4700.43.12

To cite this article: Martynenko, $\mathbf{O}$. (2021). Syntez u statychnomu j dynamichnomu aspektakh v ghenologhiji Parmenida ta Gheraklita [Synthesis in static and dynamic aspects in Parmenides' and Heraclitus' genology]. Liudynoznavchi studii: zbirnyk naukovykh prats Drohobytskoho derzhavnoho pedahohichnoho universytetu imeni Ivana Franka. Seriia "Filosofiia" - Human Studies. Series of "Philosophy": a collection of scientific articles of the Drohobych Ivan Franko State Pedagogical University, 43, 89-95, doi: https://doi.org/10.24919/2522-4700.43.12

\section{SYNTHESIS IN STATIC AND DYNAMIC ASPECTS IN PARMENIDES' AND HERACLITUS' GENOLOGY}

Summary. The aim of the article is a historical and philosophical analysis of the ancient origins of synthesis in Parmenides' and Heraclitus 'genealogy, their comparison with the Hegelian model of synthesis. Methodological principles of research: the main research method is historical and philosophical. The article also uses comparative and structural-functional methods. General scientific methods are used: analysis, synthesis, generalization, abstraction, etc. Scientific novelty: historically ontology (metaphysics of being) 
has taken a dominant position in modern philosophy, moving genology (metaphysics of the unity) aside. The category of "being" and "unity" began to be used as interchangeable, and sometimes as equivalent. This significantly influenced the development of philosophy in general, changing the specifics of the way of thinking, in particular, the cognitive operation of synthesis. The explanation of the specifics of synthesis, as well as attempts to classify its varieties, in the vast majority of philosophical works presented in modern academic literature, continues to remain unambiguous. This approach has become established in modern philosophical practice. It has undergone almost no changes in qualitative terms, in the views of representatives of national philosophy in the $20^{\text {th }}$ century. And today, they remain virtually untouched. Existing definitions and classifications of the synthesis operation are mainly descriptive. Synthesis in the traditional sense is usually associated with the name of F. Hegel. Although modern philosophical reflection based on a critique of metaphysics in the $20^{\text {th }}$ century requires a solution to the problem of contradictions. That is why it is important to take new steps in the study of the historical origins of the operation of synthesis, to reveal the genological model of its implementation, which has long been forgotten. Conclusions: in genological synthesis, in contrast to the Hegelian model, contradictions are a formal conditionality. The difference between static and dynamic models of the synthesis of Parmenides and Heraclitus is the choice of conditions for this operation - "from unity" and "to unity".

Key words: synthesis, genology, ontology, unity, being, singular, plural, whole, syncretic, contradictions.

Постановка проблеми. Для філософії поняття «єдине» так само важливе, як і поняття «буття». Залежно від того, яка із цих категорій кладеться в основу тієї чи тієї метафізичної системи, їх розрізняють як генологію та онтологію (Гайденко, 2010 , с. 14). Серед відомих представників генології - Платон, Плотін, Прокл, Микола Кузанський i до певної міри І. Кант і Й. Фіхте. Предтечами генології були філософи Ксенофан, Парменід, Геракліт. Історично склалося так, що онтологія (метафізика буття) зайняла домінуючу позицію в сучасній філософії, відсунувши на другий план генологію (метафізику єдиного). Категорії «буття» $\mathrm{i}$ «єдине» почали вживатися як взаємозамінні, а інодіяк рівнозначні (Гайденко, 2010, с. 14). Це суттєво вплинуло на розвиток філософії загалом, змінивши специфіку самого способу мислення. Як приклад візьмемо філософську аксіологію. Л. Столович (1994) - одна з найбільш значимих фігур у радянській і пострадянській аксіології - писав, «що людське світовідношення було початково синкретичним, у найдавніших текстах із великими труднощами можна відокремити один різновид ціннісного світосприйняття від іншого» (Столович, 1994, с. 13). Темі синкретичності Л. Столович присвячує доволі вагоме місце в концепції, уважаючи її початком «ціннісного мислення» у філософії цінностей (Столович, 1994, c. 13).

У радянській філософії склалося доволі упереджене ставлення до феномена синкретичності. Річ у тім, що синкретичність уважається пережитком первісного міфологічного мислення, яке донині посідає нижче місце у світоглядній ієрархії. Але Л. Столович бере слово «пережиток» у лапки, підкреслюючи його вагу, досягнення античних мислителів перед новоєвропейськими, які почали досліджувати цінність «лише у XIX столітті» (там само). На нашу думку, те, що Л. Столович називає «синкретичністю», може бути практичним наслідком застосування специфічного синтезу античними філософами. Першим, хто звернув увагу на цей нюанс, був М. Марчук (2001), який називає «синкретичне уявлення ціннісного ставлення» - «запереченням заперечення» (Марчук, 2001, с. 10), тобто синтезом. Пояснення специфіки синтезу, як і спроби класифікації його різновидів у більшості філософських праць, представлених сучасною академічною літературою, продовжує зберігати однозначність. Такий підхід став усталеним у модерній практиці філософування. Наявні визначення та класифікації операції синтезу мають переважно описовий характер: не здійснено спроб проникнення в його теоретичні витоки. Синтез у традиційному розумінні, як правило, асоціюється 3 ім'ям Гегеля. Хоча філософська рефлексія, зокрема критика метафізики у XX ст., показала, що синтез може здійснюватися на інших філософських засадах, відмінних від онтології суперечностей. Саме тому важливо здійснити нові кроки в дослідженні історичних витоків появи цієї когнітивної операції, розкрити генологічну специфіку іiі актуалізації.

Мета статті - історико-філософський аналіз античних витоків синтезу в генології Парменіда i Геракліта, їх порівняння та зіставлення з гегелівською моделлю синтезу. Досягненню мети має сприяти вирішення таких завдань: а) аналіз терміна «генологія»; б) аналіз статичної моделі синтезу в генології Парменіда; в) аналіз динамічної моделі синтезу в генології Геракліта; г) порівняння цих моделей $з$ операцією синтезу в Гегеля.

Аналіз останніх досліджень i публікацій. Грунтовний аналіз категорій «єдине» $\mathrm{i}$ «буття», генології та онтології, пояснення їх специфіки здійснив А. Гагінський (2018) у монографії «Філософія незумовлених первнів». У цій праці досліджуються три теми: буття, єдине, Бог. Ці поняття трактуються автором як незумовлені первні, що започатковували ту чи ту метафізичну епоху. 
Для античної філософії граничним первнем було єдине, або благо, для середньовічної інтелектуальної культури - Бог, для сучасності - буття.

Корисну інформацію дають енциклопедичні статті П. Гайденко: «Буття» (Гайденко, 2010а) i «Єдине» (Гайденко, 2010b). Специфіка історичного становлення понять «єдине» і «буття», особливості генологічного синтезу в статичній і динамічній інтерпретаціях у філософських системах Геракліта і Парменіда розкривають праці А. Лебедєва: «Логос Геракліта» (Лебедев, 2014), «Фрагменти ранніх грецьких філософів» (Лебедев 1989), «Геракліт» (Лебедев, 2010а), «Парменід» (Лебедев, Бородай, 2010b); О. Лосєва (2000) «Історія античної естетики. Рання класика»; Т. Румянцевої (2002) «Геракліт Ефеський»; Г. Левіна (2010) «Сдність і боротьба суперечностей»; В. Садовського (2010) «Синтез»; А. Смирнова (2010) «Рух».

Основний матеріал. Нині нюанси, пов'язані 3 операцією синтезу, як правило, асоціюються 3 ім'ям Гегеля. У діалектиці знаменитого німецького філософа синтез - це поєднання розділених частин (суперечностей) - тези й антитези. Таке уявлення про синтез онтологічне у своїх витоках. Воно неоднозначне, існують інші погляди стосовно цієї операції. В античній філософії, передусім у платонічній традиції, існував підхід, що суттєво змінює усталене уявлення про синтез, - генологія. Термін «генологія» (від поєд-

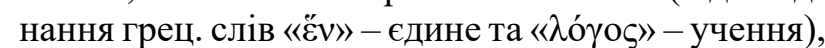
пише А. Гагінський (2018), «був уведений в обіг філософами О. Лосєвим, Е. Жильсоном, Е. Віллером» (Гагінський, 2018, с. 51).

Витоки генології варто шукати в ученні Ксенофана. Філософ учив про єдиний Усесвіт, про те, що єдине - це Бог. Ксенофан, указує А. Лебедєв (1989), був «переконаним монотеїстом» (Лебедєв, 1989, с. 17). Якщо філософ і вживав слово «боги», то лише задля дотримання «поетичної традиції» (Лебедєв, 1989, с. 17). Субстанцією Бога Ксенофана було «Єдине», а акциденціями - «вічність, незмінність, усепроникність, непорушність» (Лебедєв, 1989, с. 17). Ксенофан був учителем Парменіда. На це, зокрема, указує Аристотель (1976): «Кажуть, що Парменід був його (Ксенофана - О. М.) учнем» (Лебедєв, 1989, с. 77). Парменід відомий тим, що увів в обіг категорію «Буття» (Гайденко, 2010a, с. 337). Це поняття нині відіграє головну роль у категоріальному апараті західної філософії (Гайденко, 2010а, с. 337). Зауважимо, що для самого Парменіда ця категорія мала другорядне значення. Головна мета філософа - розв'язання проблеми «Є диного». Парменід бачив себе не онтологом (метафізиком буття), а генологом (метафізиком єдиного) (Гайденко, 2010b, c. 14).
Наскільки 3'ясування проблеми витоків онтологічного й генологічного різновиду синтезу важливе для сучасної філософії? Якщо звернутися до критики метафізики у XX ст., то можемо зауважити зростання інтересу до генології як учення, здатного подолати онтологію. А. Гагінський (2018) зазначає із цього приводу: «Воно було запропоноване як відповідь на критику М. Гайдегера ... дослідники вказували на те, що німецький філософ ігнорує неоплатонізм, центральним пунктом якого є вчення про надбуттєве Єдине» (Гагінський, 2018, с. 51). Справедливість думки А. Гагінського підтверджують слова самого М. Гайдегера (1998), який у «Пролегоменах до історії поняття часу» пише, що синтез може бути чимось іншим, ніж поєднанням суперечностей: «Синтез - це не стільки зв'язування двох раніше розділених частин, на кшталт склеювання чи спаювання речей, скільки даність предмета» (М. Гайдегера, 1998, с. 70), але «даність», про яку пише філософ, якраз і $є$ позицією античної генології. М. Гайдегер критикує німецьких ідеалістів, але ні словом не згадує античних генологів.

Істотне значення щодо появи різновидів операції синтезу у філософії відіграли розмисли Парменіда про «день» і «ніч» - «знання, якого позбавлена Ніч, - важке, щільне тіло» (Лебедев, 1989, с. 297), «шлях істини» $(\alpha \lambda \eta \dot{\theta} \theta \varepsilon 1 \alpha)$ - «що є і не бути ніяк не може» (Лебедев, 1989, с. 295) і «шлях гадки» $(\delta o ́ \xi \alpha)$ - «що не $\epsilon$ і не бути мусить неминуче» (Лебедев, 1989). Остання пара в майбутньому чітко поділила істину на абсолютну та відносну, створила прецедент для черги історичних спекуляцій щодо першості матеріального й ідеального, можливого й дійсного, суб'єктивного й об'єктивного; стала основою ідеї секулярності - «системи, що поділила всі сфери людських зв'язків» (Смирнов, 2010, с. 52).

Алегорія «світла і темряви» - обман, у який свідомо впадають смертні: «назвати іменами дві форми (день і ніч - O. М.), «одну з яких (іменувати - А. Л.) не треба» (Лебедев, 1989, с. 291). Насправді світ єдиний, і те, що здається людям «днем і ніччю», - це однорідна субстанція ефіру. День і ніч - суперечності, у які неминуче впадає людина, намагаючись пізнати істину. Будь-яка думка, що має справу з мінливим «нічним» світом, сама мінлива. Вона - лише правдоподібна гадка («гадка» не обов'язково хибна, суть у тому, що вона ніколи не досягає незаперечності істини). Мати внутрішню обов'язковість може лише «чиста» думка, закорінена в собі самій, вільна від омани.

Що ж буде предметом філософського мислення, коли «шлях істини» виведе його за межі смертного світу з усім його плинним і рухливим різноманіттям? Буття як таке: речі можуть бути такими чи іншими, але насамперед вони просто 
«€»; буття речей утворює інтелектуально досяжний засновок для будь-якого конкретного їх визначення.

Умовою використання дисциплінарної частини «шляху істини» $є$ прийняття низки філософських тверджень згідно з принципом цілісності буття і мислення («мислити і бути - те саме»): реальне лише те, що мислиме, а те, що немислиме, не існує. Зокрема, тому небуття й не існує, що воно немислиме та невимовне. Буття ж $є$ і наділене низкою характеристик, які постають наслідками заперечення небуття: буття не виникає й не зникає, воно безперервне й однорідне, залишаючись цілісним, воно ні в чому не має потреби й постає досконалою сферою, у якій немає руху.

На тезі «буття $\epsilon$, а небуття немає» грунтується вся філософія Парменіда. Єдине і буття - уже поділ. Небуття стосовно цієї пари зайве (протилежність буття - це єдине, отже, небуття немає). Згідно із цією логікою, рухові відмовлялося в праві на існування: його не було через те, що він порушував правило цілісності буття і мислення, незмінності. Виходить, що операція «синтезу» в цій схемі неможлива принаймні на перший погляд. Якщо вдатися до інтерпретації, то можна зауважити взаємодію шляху істини і шляху гадки (докси). Синтез у Парменіда буде виглядати не поєднанням суперечностей, а їх цілісним сприйняттям. В опозиції (поняття «опозиція» в цьому контексті варто розуміти в межах традиційної лінгвістики, відрізняти від терміна «бінарна опозиція», що тлумачиться в дусі «дихотомічної фонології Р. Якобсона» (Булыгина, 1998, с. 348)) істина/омана до істини не можна додати хибу, як у гегелівській діалектиці. Члени опозицій у Парменіда не перебувають у суперечності. Те, що видається за суперечність, - «обман, у який мимоволі впадають смертні». Тобто опозиція Парменіда не суперечність у формальному розумінні. Суперечності - як контрадикторні, так і контрарні - мають на увазі поділ, якого в генології античного мислителя бути не могло: «Єдине усе, узяте у своїй сукупності, так що «буття має середину і кінці», а «правда не випустила зі своїх кайданів народження і смерті, але (міцно - О. Л.) тримає їх» (Лосев, 2000, с. 355). Члени опозицій Парменіда не «суперечать» один одному, а розрізняються в певній цілісній сукупності. Про специфіку опозиційного розрізнення у філософії Парменіда пише О. Лосєв (2000):

Характерно, що один і той самий фрагмент (Парменід, А 22 - О. Л.) говорить і про хибність чуттєвості, і про пов'язаність їі зі світом становлення, тут немає жодної суперечності, а є лише єдина й цілісна концепція, яка не має нічого спільного ні з суб'єктивізмом, ні дуалізмом (Лосев, 2000 , c. 355$)$.
Окремо зауважимо щодо так званої «Тези Гегеля» (Aufhebung, закон заперечення заперечення, синтез), яку Г. Левін (2010) подає як твердження, «що дві суперечності можуть бути одночасно, в одному й тому ж розумінні притаманні одному об'єктові» (Левін, 2010, с. 19). Здавалось би, цю тезу цілком можна приписати Парменідові: «Буття має середину і кінці» ..., «Правда... тримає їх». Але те, що для Парменіда було концептуальним ядром філософії (розрізнення в межах певної цілісності), для Г. Гегеля (1937) стало предметом критики в контексті його діалектики:

Парменіду доводиться мати справу 3 видимістю і гадкою, з протилежністю буття і істини. Синтез містить у собі й показує неістинність зазначених вище абстракцій; у ньому вони перебувають у єдності зі своїм іншим, дані, отже, не як такі, що самі собою існують, не як абсолютні, а цілком як відносні (Гегель, 1937, с. 88).

В оптиці Гегеля генологія Парменіда постає помилкою - хибною позицією. Небажання філософа визнати існування метафізики єдиного як альтернативної щодо онтології логіки конструювання картини світу привело його до однобічного висновку.

Коли Парменід будував свою філософію, Гераклітом була створена перша форма діалектики (Румянцева, 2002). Може скластися враження, що філософ, який створив діалектику, діяв в оптиці, наближеній до нашого розуміння діалектики гегельянського штибу, але А. Лебедєв (2010а) вказує, що Геракліт, як і Парменід, був метафізиком єдиного: «Фундаментальна опозиція, довкола якої оберталася думка Геракліта, «одне» і «множинне» (або «все»). В онтології, космології, теології, політиці й етиці Геракліт утверджував примат «одного» над «множинним» (Лебедев, 2010a, с. 504).

У філософії Геракліта синтез починається 3 концептуального узаконення руху, релятивності (Мартиненко, 2010). «Усе тече» (panta rei) - теза релятивності Геракліта. Розширена версія цього вислову, за Плутархом (2012), звучить так:

Бо неможливо увійти двічі в ту саму річку [F 91a] і двічі торкнутися смертної субстанції в тому ж стані, але спритність і швидкість перетворення такі, що вона розсіюється, і збирається знову сама, а потім ... складається і спадає, приходить і йде [F 91b] $\|$... бо інші течуть води» [cf. F 12a] (Муравьев, 2012, с. 149).

Отже, Геракліт спробував розв'язати проблему руху через його визнання. На нашу думку, це був аналіз шляхів функціювання Єдиного у світі змін - абсолютної плинності: «Усе перебуває в стані руху, а спокій є видимістю» (Смирнов, 2010, с. 596). Це твердження, на думку А. Лебедєва (2014), показує принципову відмінність між 
системами єдиного в Парменіда та Геракліта: рух став фактором, який повністю змінив характер логіки метафізичних маніпуляцій із Сдиним:

I в Геракліта, i в Парменіда буття відповідає «єдиному», а становлення - «множинності», що сприймається як сукупність усіх пар суперечностей. ... єдине розуміється як умоглядна істина, а множинність - як ілюзія, що є обманом чуттєвого сприйняття... Відмінність у тім, що в Парменіда онтологічний абсолют нерухомий i незмінний, а в Геракліта сповнений енергії, руху та безперервної циклічної зміни (Лебедев 2014, с. 53).

У діалектиці Геракліта (2012) можемо знайти роздуми щодо результату синтезу, який, на думку філософа, полягав у гармонії поєднаних суперечностей:

Природа насолоджується суперечностями й уміє вилучати 3 них співзвучне, 3 них, а не 3 подібних, як чоловік зближується із жінкою, а не із собі подібним і досягає початкової згоди за допомоги протилежного, а не однакового. Мистецтво, наслідуючи природу, робить те саме. Живопис, змішуючи природу білого і чорного, жовтого і червоного, створює зображення, відповідно до моделі; музика, змішуючи високі і низькі, довгі i короткі тони, досягає єдиної гармонії з різних звуків; граматика, поєднуючи приголосні і голосні, формує за їх допомоги свою майстерність (Муравьев, 2012, с. 134).

Визнаючи рух, Геракліт також визнав розділення цілого/єдиного на частини. Синтез - це «гармонія співзвучного» в такому поділі. Слова

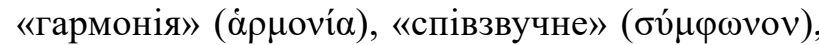

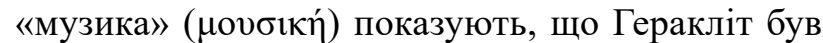
добре знайомий з ідеями піфагорійської філософіï, імовірно, був під їхнім впливом. Апеляція до природи виглядає відсилкою до натуралізму фізиків.

Ще одна версія синтезу Геракліту походить i3 герменевтичного тлумачення характеру його філософіï: «Геракліт, спираючись на граматичну аналогію, засвідчену фрагментом 106 L (У 10), пояснює свій філософський метод як герменевтику, як мистецтво читання й тлумачення космічного логосу чи вічної книги природи» (Лебедев 2014 , с. 64). Але й у цій оптиці Геракліт бачить синтез як «гармонію суперечностей»: «Під фр. 1 L (У 50) він використовує пророчу формулу «і не моє це слово...» Геракліт уважав себе пророком Аполлона, і саме тому знаходив найвищу мудрість у законі тотожності, або гармонії суперечностей» (Лебедев 2014, с. 64).

«Теза Гегеля» в діалектиці Геракліта стає схожою на саму себе. Діалектика Геракліта (2012) відповідає їі виразу, хоч і не збігається з їі ідеєю:

Морок і світло, добро і зло не різні речі, але одні й ті ж... День і ніч - одне [F 57] ... А також добро i зло [58]... I пряме і криве - одне і те ж [59]... i верх і низ - одне і те ж [F 60] ... Брудне і чисте одне і те ж [F 61] ... безсмертне смертне і смертне безсмертне [F 62] (Муравьев, 2012, с. 135).

Вираження одне, але форми різні: «води рік» Гегеля не розвіюються в сутньому, щоб швидкошвидко зібратися знову. Синтез у Гегеля теза/ антитеза = синтез, де синтез буде спекулятивним висновком. Теза з абстрактної перетворюється на більш конкретну, збагатившись елементом істинності, що первісно містилася в антитезі. Усе це відбувається в безперервному русі, спрямованому на синтез абсолюту (духу, ідеї). У Геракліта синтез був іншим: об'єднання елементів як «гармонія співзвучного», що вже містить у собі єдине. Рух до єдиного - не спекуляція, а гармонія.

Звісно, ми не можемо стверджувати, що Гегель був переконаним адептом ідей «Науки логіки», його пізні роздуми щодо природи антиномій стали причиною появи позиції, де вони постають у несподівано впізнаваному вигляді: «Прихильники «тези Гегеля».... (уважають - O. M.), що антиномії - це не помилки, а форми істинного відображення об'єктивних суперечностей» (Левін, 2010, с. 19). Спроба трактувати антиномію цілісно - чим не генологія?

Висновки. Перший висновок буде стосуватися динаміки буття довкола єдиного. Сдине Парменіда своєю сталістю відштовхує від себе плинність у спільний простір. Відбувається своєрідна конверсія єдиного в буття. Це створює певну протяжність, що має кінці, «які тримає правда» - так виглядає статична модель синтезу. У Геракліта, навпаки, рух починається зі сфери плинного до єдиного, речі ніби бажають знайти свою цілісність. Спочатку конвергенція в напрямі до єдиного, а потім - гармонія, що теж $є$ процесом, який можна сприймати цілісно, наприклад, як мелодію чи картину. Логос-вогонь Геракліта пульсує - «згасає і спалахує» (Муравьев, 2012, с. 96), тобто рух іде в обидві сторони, але гармонія досягається все ж таки з боку плинного. У цьому нюансі відображена специфіка моделі синтезу Геракліта: суперечності постають умовою цілісності. Як лише щось видається за суперечність - їх можна сприймати цілісно в гармонічному поєднанні. Отже, принципову відмінність моделей синтезу в Геракліта і Парменіда можна відобразити початком здійснення операції: «від єдиного» і «до єдиного».

Другий висновок стосується порівняння синкретичних систем Парменіда і Геракліта 3 діалектикою Гегеля. Перше, що впадає в око, - те, що Гегель визнавав суперечності, на відміну від своїх античних попередників. Однак аналіз «тези Гегеля» показує, що німецький філософ, незважаючи на свою позицію стосовно суперечностей, 
шукав шляхи їхнього примирення. Цей аспект, на нашу думку, потрібно окремо дослідити, визначити його справедливість або хибність.

У підсумку зазначимо, що започаткування Парменідом проблеми синтезу - цілісності/розділеності буття і єдиного - стало долею європейської філософської думки на два 3 половиною тисячоліття. По-перше, вона лягла в основу самовизначення філософії: набула сили забобону в упевненості, що повсякденний досвід, обмежений сферою гадки, і лише пориваючи 3 нею, стаючи «чистим» і самодостатнім, мислення здатне осягати справжню реальність. Гадка стала атрибутом релятивізму. По-друге, ця опозиція визначила складні й історично мінливі зв'язки між різноманітними глобальними соціокультурними системами світогляду: наукою та релігією, філософією та міфом, мистецтвом і технікою тощо.

\section{ЛІТЕРАТУРА}

1. Аристотель. Сочинения : в 4 т. / гл. ред. В.Ф. Асмус. Москва : Мысль, 1976. Т. 1. 550 с.

2. Булыгина Т.В. Крылов С.А. Оппозиции. Языкознание. Большой энциклопедический словарь/гл. ред. В.Н. Ярцева. Москва : Большая российская энциклопедия, 1998. С. 348.

3. Гагинский А.М. Философия беспредпосылочных начал. Москва : ИФ РАН, 2018. 194 с.

4. Гайденко П.П. Бытие. Новая философская энщиклопедия : в 4 т. / предс. ред. совета В.С. Степин. Москва : Мысль, 2010а. Т. 1. С. 337-345.

5. Гайденко П.П. Единое. Новая философская энциклопедия : в 4 т. / предс. ред. совета В.С. Степин. Москва : Мысль, 2010b. Т. 2. С. 14-18.

6. Гегель. Наука логики. Сочинения : в 14 т. / ред. М.Б. Митин. Москва, Ленинград : Государственное социальноэкономическое издательство, 1937. Т. 5.814 с.

7. Герасимов С.В. Постсекулярность как индикатор расширения и смены концепта реальности. Человек. Культура. Образование. 2007. № 4 (26). С. 47-60.

8. Лебедев А.В. Гераклит. Новая философская энциклопедия : 4 т. / предс. ред. совета В.С. Степин. Москва : Мысль, 2010а. Т. 1. С. 504-206.

9. Лебедев А.В. Логос Гераклита. Реконструкция мысли и слова (с новым критическим изданием фрагментов). Санкт Петербург : Наука, 2014. 533 с.

10. Лебедев А.В. Фрагменты ранних греческих философов (Часть I). От эпических теокосмогоний до возникновения атомистики. Москва : Наука, 1989. 576 с.

11. Лебедев А.В., Бородай Т.Ю. Парменид. Новая философская энциклопедия : 4 т. / предс. ред. совета В.С. Степин. Москва : Мысль, 2010b. Т. 3. С. 202-204.

12. Левин Г.Д. Единство и борьба противоположностей. Новая философская энииклопедия : в 4 т. / предс. ред. совета В.С. Степин. Москва : Мысль, 2010. Т. 2. С. 272-274.

13. Лосев А.Ф. История античной эстетики : в 8 т. (7 и 8 т. в 2 кн.) / гл. ред. В.И. Галий. Харьков : Фолио; Москва : ООО «Издательство АСТ», 2000. Т. 1 : Ранняя классика. 624 с.

14. Мартиненко О.П. Концептуальний аналіз філософського релятивізму. Науковий вісник Чернівецького університету. Серія «Філософія» : збірник наукових праць. Чернівці : Рута, 2010. № 534-535. С. 43-48.

15. Марчук М.Г. Ціннісні потенції знання. Чернівці : Рута, 2001. 319 с.

16. Муравьев С.Н. Гераклит Эфесский: все наследие: на языках оригинала и в русском переводе: краткое издание. Москва : ООО Ад Маргинем Пресс, 2012. 416 с.

17. Румянцева Т.Г. Гераклит Эфесский. История философии: Энциклопедия / гл. ред. А.А. Грицанов. Минск : Интерпрессервис; Книжный Дом. 2002. С. 238-239.

18. Садовский В.Н. Синтез. Новая философская энцииклопедия : 4 т. / предс. ред. совета В.С. Степин. Москва : Мысль, 2010. Т. 3. С. 546-547.

19. Смирнов А.В. Движение. Новая философская эничиллопедия : 4 т. / предс. ред. совета В.С. Степин. Москва : Мысль, 2010. Т. 1. С. 596-600.

20. Столович Л.Н. Красота. Добро. Истина: Очерк истории эстетической аксиологии. Москва : Республика, 1994. 464 с.

21. Хайдеггер М. Пролегомены к истории понятия времени. Томск : Водолей, 1998. 384 с.

\section{REFERENCES}

1. Aristotel', (1976). Sochinenija [Essays] (Vols. 1-4, V. 1). Moskva: Mysl' [in Russian].

2. Bulygina, T.V., \& Krylov, S.A. (1998). Oppozicii [Opposition]. In Jazykoznanie. Bol'shoj jenciklopedicheskij slovar'Big encyclopedic dictionary (pp. 348). Moskva: Bol'shaja Rossijskaja jenciklopedija [in Russian].

3. Gaginskij, A.M. (2018). Filosofija bespredposylochnyh nachal [The philosophy of unprecedented beginnings]. Moskva: IF RAN [in Russian].

4. Gajdenko, P.P. (2010a) Bytie [Being]. In Novaja filosofskaja jenciklopedija - New Philosophical Encyclopedia. (Vols. 1-4, V. 1); (pp. 337-345). Moskva: Mysl' [in Russian].

5. Gajdenko, P.P. (2010b). Edinoe [Unity]. In Novaja filosofskaja jenciklopedija - New Philosophical Encyclopedia. (Vols. 1-4, V. 1); (pp. 337-345). Moskva: Mysl' [in Russian].

6. Gegel'. (1937). Nauka logiki [Science of logic]. (Vols. 2). Moskva, Leningrad: Gosudarstvennoe social'nojekonomicheskoe izdatel'stvo [in Russian].

7. Gerasimov, S.V. (2017). Postsekuljarnost' kak indikator rasshirenija i smeny koncepta real'nosti [Post-secularity as an indicator of the expansion and change of the concept of reality]. Chelovek. Kul'tura. Obrazovanie - Human. Culture. Education, 4 (26), 47-60 [in Russian]. 
8. Lebedev, A.V. (2010a.). Geraklit [Heraclitus]. In Novaja filosofskaja jenciklopedija-New Philosophical Encyclopedia. (Vols. 1-4, V. 1); (pp. 504-206). Moskva: Mysl' [in Russian].

9. Lebedev, A.V. (2014). Logos Geraklita Rekonstrukcija mysli i slova (s novym kriticheskim izdaniem fragmentov) [Logos of Heraclitus Reconstruction of thought and word (with new critical edition of fragments)]. Sankt Peterburg: Nauka [in Russian].

10. Lebedev, A.V., \& Borodaj T.Ju. (2010b). Parmenid [Parmenides]. In Novaja filosofskaja jenciklopedija - New Philosophical Encyclopedia. (Vols. 1-4, V. 3); (pp. 202-204). Moskva: Mysl' [in Russian].

11. Lebedev, A.V. (Eds.). (1989). Fragmenty rannih grecheskih filosofov (Chast' I). Ot jepicheskih teokosmogonij do vozniknovenija atomistiki [Fragments of the Early Greek Philosophers (Part I). From epic theocosmogonies to the emergence of atomism]. Moskva: Nauka [in Russian].

12. Levin, G.D. (2010). Edinstvo i bor'ba protivopolozhnostej [The unity and struggle of opposites]. In Novaja filosofskaja jenciklopedija - New Philosophical Encyclopedia. (Vols. 1-4, V. 2); (pp. 272-274) Moskva: Mysl' [in Russian].

13. Losev, A.F. (2000). Istorija antichnoj jestetiki. Rannjaja klassika [History of ancient aesthetics. Early classics], (Vols. 1-8, V. 1). Har'kov: Folio; Moskva: OOO «Izdatel'stvo ACT» [in Russian].

14. Martynenko, O.P. (2010). Konceptualjnyj analiz filosofsjkogho reljatyvizmu [Conceptual analysis of philosophical relativism]. Naukovyj visnyk Chernivecjkogho universytetu: Zbirnyk naukovykh pracj. Filosofija - Scientific Bulletin of Chernivtsi University: Collection of scientific works. Philosophy, 534-535, 43-48 [in Ukrainian].

15. Marchuk, M.G. (2001). Cinnisni potenciji znannja [Value potentions of knowledge]. Chernivci: Ruta [in Ukrainian].

16. Murav'ev, S.N. (Eds.). (2012). Geraklit Jefesskij: vse nasledie: na jazykah originala i v russkom perevode: kratkoe izdanie [Heraclitus of Ephesus: the entire legacy: in the original languages and in Russian translation: a short edition]. Moskva: OOO «Ad Marginem Press» [in Russian].

17. Rumjanceva, T.G. (2002). Geraklit Jefesskij [Geraklit Jefesskij]. In Istorija filosofii: Jenciklopedija - History of Philosophy: An Encyclopedia, (pp. 238-239). Minsk: Interpresservis; Knizhnyj Dom [in Russian].

18. Sadovskij, V.N. (2010). Sintez [Synthesis]. In Novaja filosofskaja jenciklopedija - New Philosophical Encyclopedia. (Vols. 1-4, V. 3); (pp. 546-547). Moskva: Mysl' [in Russian].

19. Smirnov, A.V. (2010). Dvizhenie [Motion]. In Novaja filosofskaja jenciklopedija - New Philosophical Encyclopedia. (Vols. 1-4, V. 1); (pp. 596-600). Moskva: Mysl' [in Russian].

20. Stolovich, L.N. (1994). Krasota. Dobro. Istina: Ocherk istorii jesteticheskoj aksiologii [Beauty, Goodness, Truth: essay on the history of aesthetic axiology]. Moskva: Respublika [in Russian].

21. Hajdegger, M. (1998). Prolegomeny $k$ istorii ponjatija vremeni [Prolegomena to the history of the concept of time]. Tomsk: «Vodolej» [in Russian]. 